\title{
The Influence of Emotional Intelligence and Teacher Workload on Teacher Performance
}

\author{
Annisa Husninadiyah Susanto ${ }^{1 *}$, I. B Gede Surya Abadi ${ }^{2}$ (iD \\ 1,2 Pendidikan Guru Sekolah Dasar, Universitas Pendidikan Ganesha, Singaraja, Indoensia \\ *Corresponding author: annisahusninadiyahsusanto12@undiksha.ac.id
}

\begin{abstract}
Abstrak
Masih banyak guru yang belum mampu bertindak professional. Kurangnya kecerdasan emosional serta motivasi guru menyelesaikan tugas menghambat kinerja guru. Penelitian ini merupakan penelitian ex post facto. Populasi dalam penelitian melibatkan 46 orang responden. Teknik yang digunakan untuk mengumpulkan data adalah observasi, wawancara, dan kuesioner. Instrument yang digunakan dalam menganalisis data adalah kuesioner. Metode analisis data yang digunakan yaitu terdiri dari uji asumsi klasik serta uji hipotesis. Uji asumsi klasik terdiri dari uji normalitas residual, uji heterokedastiistas, uji multikolinearitas serta uji linearitas berbantuan SPSS. Uji hipotesis menggunakan analisis regresi linear sederhana dan analisis regresi linear berganda berbantuan SPSS. Hasil penelitian berdasarkan analisis regresi linear sederhana dan analisis regresi linear ganda menunjukkan bahwa (1) Tidak terdapat pengaruh kecerdasan emosional terhadap kinerja guru. (2) Terdapat pengaruh beban kerja terhadap kinerja guru dengan sumbangan sebesar $98 \%$. (3) Terdapat pengaruh kecerdasan emosional dan beban kerja guru terhadap kinerja guru dengan sumbangan sebesar 14,3\%. Dapat disimpulkan bahwa terdapat pengaruh kecerdasan emosional dan beban kerja guru terhadap kinerja guru sekolah dasar.
\end{abstract}

Kata kunci: Kecerdasan Emosional, Beban Kerja Guru, Kinerja Guru

\section{Abstract}

There are still many teachers who have not been able to act professionally. Lack of emotional intelligence and motivation of teachers to complete tasks hampers teacher performance. This research was an ex post facto research. The population in the study involved 46 respondents. The techniques used to collect data are observation, interviews, and questionnaires. The instrument used in analyzing the data is a questionnaire. The data analysis method used consists of classical assumption tests and hypothesis testing. Classical assumption test consisted of residual normality test, heteroscedasticity test, multicollinearity test, and SPSS-assisted linearity test. Hypothesis testing used simple linear regression analysis and multiple linear regression analysis assisted by SPSS. The study results based on simple linear regression analysis and multiple linear regression analysis showed that (1) there was no effect of emotional intelligence on teacher performance. (2) There was an effect of workload on teacher performance with a contribution of $98 \%$. (3) There is an influence of emotional intelligence and teacher workload on teacher performance with a contribution of $14.3 \%$. It can be concluded that there is an influence of emotional intelligence and teacher workload on the performance of elementary school teachers.

Keywords: Emotional Intelligence, Teacher Workload, Teacher Performance

$\begin{array}{ll}\text { History: } & \text { Publisher: Undiksha Press } \\ \text { Received : February 12, } 2021 & \text { Licensed: This work is licensed under } \\ \text { Revised : March 16, 2021 } & \text { a Creative Commons Attribution 3.0 License } \\ \text { Accepted : April 01, 2021 } & \text { CC) (P) }\end{array}$

\section{Introduction}

The school consists of several levels of education, one of which is elementary school or elementary school. Schools are formal educational institutions designed specifically for the teaching of students under the supervision of teachers (Krissandi \& Rusmawan, 2015; Wuryandani, Sapriya, \& Budimansyah, 2014). At this level, the formation of the quality of education for the nation's children improves the quality of human resources. The quality of education involves various elements, including teachers, students, and other education personnel (Kristiantari, 2015; Trianingsih, 2016). Teachers, as educators, play an important role in achieving educational goals. The achievement of these goals is closely related to the teacher's performance (Darmadi, 2015; Wahyono, Husamah, \& Budi, 2020). Internal and external factors support a teacher's performance (Dewi, 2018; Utami \& Hasanah, 2019). 
But in reality, many teachers have not been able to act professionally (Dewi, 2018; Wardani, 2012). This problem was found in one elementary school. Based on the results of observations and interviews conducted in Gugus II, South Kuta, it was found that problems were related to aspects of teacher emotional intelligence. There were still teachers who could not understand the conditions and emotions of other people or teachers' colleagues. Lack of motivation to complete tasks, inability to build good relationships with co-workers, and inability to manage emotions in dealing with work situations can hinder a teacher's performance. About the workload aspect, there are still many teachers who carry out tasks with an inappropriate amount of work, for example, teachers concurrently as school administration officers, and others so that by carrying out tasks beyond the capacity of a teacher, they can hinder the performance of teachers as educators.

Performance is achieved from work carried out by employees in an organization with full responsibility according to their abilities (Salbiyah \& Mahardhika, 2017; Supriyadi \& Sarino, 2019). Teacher performance is teachers' work performance in quality and quantity in carrying out their duties based on their pedagogic competence, professional competence, personality competence, and social competence (Lonto, 2016; Mangkunegara, 2015). Teacher performance is important and can be said as one of the efforts to optimize the realization of the ability and responsibility of teachers in carrying out their duties. The performance of teachers through carrying out their duties as educators, teachers, and trainers of their students is expected to make a meaningful contribution to the achievement of the educational goals that have been set because teachers are the backbone of educational activities, especially those related to teaching and learning activities (Karlina, Sari, \& Munzir, 2014; Yulianingsih \& Sobandi, 2017).

Various factors can affect the performance of teachers in schools. The existence of teachers in carrying out their duties and obligations cannot be separated from the influence of internal and external factors that impact changes in teacher performance (Astuti, Rokhmat, \& Sudirman, 2017; Hasibuan \& Munasib, 2020). Several factors that shape teacher performance can be seen from several aspects such as personality and dedication, professional development, teaching ability, inter-relations and communication, community relations, discipline, welfare, and work climate. Factors that affect teacher performance include internal and external factors. Internal factors such as motivation, personality, skills, abilities, experience, and family background, external factors include the work environment, leadership, salary, and infrastructure.

Associated with internal factors in carrying out their duties as educators, the dimensions of the teacher's personality affect the success of teachers in carrying out their duties. The teacher's personality is part of the teacher's self. The teacher's ability to control himself is part of emotional intelligence. Emotional intelligence affects a person's success at work (Akimas, 2016; Erdiyanti, 2018). Emotional intelligence is the ability to sense, understand, and effectively determine emotional sensitivity as a source of human energy, information, and influence (Satriyono \& Vitasmoro, 2018; Zahriati, 2016). Teachers who have emotional intelligence are always enthusiastic in carrying out their duties and trying to improve their abilities (Erdiyanti, 2018). The ability and success in completing its duties are motivated by skills and intellectuality, and emotional intelligence. Other research also states that a good IQ can be successful in the future, but emotional intelligence is also important (Dharmawan, 2013).

Another factor that plays a role in the performance of a teacher is external factors. The frequency of work in a certain period is part of the external factors that play a role in a teacher's performance. The frequency of work and responsibilities received by someone who is done within a certain period is called workload (Purwanti, 2018). The workload is several activities or tasks that have a period to be carried out by workers, which in its implementation 
are required to exert more capabilities than the individual (Darma, 2018; Sunarso \& Kusdi, 2010; Yanti \& Saluy, 2019). Teachers' workload as tasks and obligations that are the teacher's responsibility includes planning learning, implementing learning, assessing learning outcomes, guiding and training students, and carrying out additional tasks attached to the implementation of main activities following the workload (Sabon, 2020). Previous research stated that workload affects teacher performance (Astuti, 2017; Sunarso \& Kusdi, 2010). Based on the explanation above, it can be concluded that emotional intelligence and workload affect teacher performance. This study aims to analyze teachers' emotional intelligence and workload on the performance of elementary school teachers.

\section{Methods}

This type of research was an ex post facto research by examining two independent variables and one dependent variable. The population in this study were 46 PNS teachers in gugus II elementary schools in South Kuta consisting of SD No.1 Tanjung Benoa, SD No. 2 Tanjung Benoa, SD No. 2 Benoa, SD No. 5 Benoa, SD No. 6 Benoa, SD No. 8 Benoa. This study used a total sample technique. All population members were used as samples. The techniques used in collecting data were observation, interviews, and questionnaires. The instrument used in collecting data was a questionnaire. The questionnaire used a Likert scale 4 , which consisted of answers strongly agree, agree, disagree, and strongly disagree. The data analysis method used consists of classical assumption tests and hypothesis testing. Classical assumption tests consisted of residual normality tests, heteroscedasticity tests, multicollinearity tests, and SPSS-assisted linearity test. Hypothesis testing used simple linear regression analysis and multiple linear regression analysis assisted by SPSS.

\section{Results and Discussion}

Based on the research results using a questionnaire instrument, the results obtained are descriptively presented in the following Table 1.

Table 1. Results of Descriptive Statistics

\begin{tabular}{ccccc}
\hline Variable & $\begin{array}{c}\text { Minimum } \\
\text { Score }\end{array}$ & $\begin{array}{c}\text { Maximum } \\
\text { Score }\end{array}$ & \multicolumn{2}{c}{ Mean Statistic Std. Deviation } \\
\hline Teacher Performance & 67.00 & 92.00 & 78.2609 & 6.28025 \\
Emotional Intelligence & 97.00 & 128.00 & 112.1087 & 8.35924 \\
Workload & 41.00 & 63.00 & 48.9348 & 4.10638 \\
\hline
\end{tabular}

This study also describes the data ideally according to the steps presented by (Ananda $\&$ Fadhli, 2018) done manually and are presented in the following Table 2.

Table 2. Description of Ideal Descriptive Statistics

\begin{tabular}{lcccc}
\hline \multicolumn{1}{c}{ Site } & Lowest Score & Highest Score & Mean Ideal Ideal Std. Deviation \\
\hline Teacher Performance & 25 & 100 & 62.5 & 12.5 \\
Emotional Intelligence & 40 & 160 & 100 & 20 \\
Workload & 17 & 68 & 42,5 & 8,5 \\
\hline
\end{tabular}

Based on Table 2, it can be seen data from each variable, emotional intelligence (X1), workload (X2), and teacher performance (Y). The maximum score obtained from each variable is $128,63,92$. Meanwhile, the minimum score obtained from each variable is 97,41 , 67. The standard deviation obtained from each variable is $6.28,8.35$, and 4.10. Compared 
with Table 2, the ideal mean of the teacher performance variable is 62.5 , emotional intelligence is 100 , and the teacher's workload is 42.4 . Then the ideal standard deviation of the teacher performance variable is 12.5 , emotional intelligence is 20 , and teacher workload is 8.5. Furthermore, based on the acquisition of ideal descriptive statistics, research data can be categorized with the following explanation. The ideal average score of teacher performance is 62.5 , and the ideal standard deviation of teacher performance is 12.5 . Then from the score obtained, the data can be categorized into three categories, high, medium, and low, which are shown in the following Table 3.

Table 3. Categorization of Teacher Performance in Gugus II Elementary Schools in South Kuta

\begin{tabular}{lcccl}
\hline \multicolumn{1}{c}{ Category } & Interval & Frequency & Percentage & Category \\
\hline High & $X>75$ & 26 & $57 \%$ & High \\
Medium & $50<X \leq 75$ & 20 & $43 \%$ & Medium \\
Low & $X<50$ & 0 & $0 \%$ & Low \\
\hline
\end{tabular}

It can be concluded that the performance of teachers at SD Gugus II in South Kuta is in the high category with a percentage of 57\%, with a frequency of 26 of the 46 teachers studied. Then the ideal average score of emotional intelligence is 100 , and the ideal standard deviation of emotional intelligence is 20 . Then, from the acquisition of these scores, the data can be categorized into three categories: high, medium, and low, shown in the following Table 4.

Table 4. Categorization of Teacher Emotional Intelligence in Gugus II Elementary Schools in South Kuta

\begin{tabular}{lcccl}
\hline \multicolumn{1}{c}{ Category } & Interval & Frequency & Percentage & Category \\
\hline High & $\mathrm{X}>120$ & 10 & $22 \%$ & High \\
Medium & $80<\mathrm{X} \leq 120$ & 36 & $78 \%$ & Medium \\
Low & $\mathrm{X}<80$ & 0 & $0 \%$ & Low \\
\hline
\end{tabular}

It can be concluded that the emotional intelligence of the teachers of SD Gugus II in South Kuta is in the moderate category with a percentage of $78 \%$, which is 36 of the 46 teachers studied. Furthermore, the ideal workload average score is 42.5 . The ideal workload standard deviation is 8.5 , which can be categorized into three categories, high, medium, and low, shown in the following Table 5.

Table 5. Categorization of Teacher Workload at Gugus II Elementary Schools in South Kuta

\begin{tabular}{lcccl}
\hline \multicolumn{1}{c}{ Category } & Interval & Frequency & Percentage & Category \\
\hline High & $X>51$ & 12 & $26 \%$ & High \\
Medium & $51<X \leq 34$ & 34 & $74 \%$ & Medium \\
Low & $X<34$ & 0 & $0 \%$ & Low \\
\hline
\end{tabular}

It can be concluded that the workload of teachers at SD Gugus II in South Kuta is in the medium category with a percentage of $74 \%$ or 34 of the total 46 teachers studied. Before testing the hypothesis, an assumption test was carried out consists of a residual normality test, linearity test, heteroscedasticity test, and multicollinearity test. The test results are presented in the following Table 6 . 
Table 6. Residual Normality Test

\section{Unstandardized Residual}

Asymp. Sig. (2-tailed) ${ }^{\mathrm{c}} \quad 0.422$

Based on the Table 6, the significance score of the residual data normality test is 0.422. The determination of the normality of the regression residuals is seen from the significance score. If the significance score. $>0.05$, it can be said that the regression residuals are normally distributed. Based on the acquisition of a significance score of $0.422>0.05$, the data is normally distributed.

Table 7. Linearity Test

\begin{tabular}{clcc}
\hline Variable & & F & Sig. \\
\hline $\mathrm{Y} * \mathrm{X} 1$ & Deviation from Linearity & 1.317 & 0,262 \\
$\mathrm{Y} * \mathrm{X} 2$ & Deviation from Linearity & 0,998 & 0,483 \\
\hline
\end{tabular}

The data criteria can be linear if the calculated $\mathrm{F}$ score $<\mathrm{F}$ table is about the linearity test. Meanwhile, if the calculated F score $>\mathrm{F}$ table, the data has a non-linear pattern (Ananda \& Fadhli, 2018). The $\mathrm{F}$ score of the linearity test of emotional intelligence and teacher performance is 1.317 . The $\mathrm{F}$ table score is 2.04 , which means $1.317<2.04$ so that emotional intelligence and teacher performance can be said to be linear. Then the $\mathrm{F}$ score of the teacher's workload is 0.988 , and the F table score is 2.02 , which means $0.988<2.02$, so that the teacher's workload and teacher performance can be said to be linear. The significance score of the emotional intelligence heteroscedasticity test was 0.590 , and the teacher's workload was 0.380 . The basis for decision-making on the heteroscedasticity test is that if the significance score is $>0.05$, there is no heteroscedasticity. On the other hand, if the significance score is $<0.05$, then heteroscedasticity occurs. Based on the results obtained, the significance score of emotional intelligence is $0.590>0.05$, and the teacher's workload is $0.380>0.05$, meaning that there is no heteroscedasticity in the regression model. The VIF scores of the emotional intelligence multiple linearity test and the teacher's workload were 1.182. The data criteria can be said to be multicollinear if the VIF score is $>10.00$. On the other hand, if the VIF score is $<10.00$, it can be said that there is no multicollinearity. Based on the results obtained, the VIF score of emotional intelligence and emotional intelligence burden of $1.182<10$ shows no multicollinearity of emotional intelligence and teacher workload.

Table 8. Summary of simple regression results $\mathrm{X}_{1}$ and $\mathrm{Y}$

\begin{tabular}{ccccc}
\hline Variable & $\mathbf{R}$ & Coefficient & $\mathbf{T}$ & Sig. \\
\hline Emotional intelligence & $0,140^{\mathrm{a}}$ & 66,435 & 0,941 & 0,352 \\
& & 0,105 & & \\
\hline
\end{tabular}

Based on the table, the R2 score of 0.020 means that emotional intelligence contributes to teacher performance of $2 \%$ while other variables influence the remaining $98 \%$. The constant score is 66,435, which means that statistically, without X1 (emotional intelligence), the magnitude of Y (teacher performance) is 66,435. Then, the coefficient score of the $\mathrm{X} 1$ variable is 0.105 , which means that if $\mathrm{X} 1$ (emotional intelligence) has increased by $1 \%$, then Y (teacher performance) will increase by 0.105 or by $10.5 \%$. The coefficient score of the $\mathrm{X} 1$ variable is positive for $\mathrm{Y}$. This means that the higher X1 (emotional intelligence), the $\mathrm{Y}$ (teacher performance) will also be higher and vice versa. The significant score of the $\mathrm{X} 1$ variable is $0.352>0.05$, so there is no significant effect of emotional intelligence on 
teacher performance at Gugus II Elementary Schools in South Kuta for the 2020/2021 Academic Year.

Table 9. Summary of simple regression results $\mathrm{X}_{2}$ and $\mathrm{Y}$

\begin{tabular}{ccccc}
\hline Variable & R & Coefficient & T & Sig \\
\hline Workload & 0,098 & 101,749 & $-2,193$ & 0,034 \\
& & $-0,480$ & & \\
\hline
\end{tabular}

Based on the table, the score of R2 is 0.98 , which means that the amount of the contribution of the $\mathrm{X} 2$ variable (teacher workload) in influencing $\mathrm{Y}$ (teacher performance) is $98 \%$. In comparison, other variables influence the remaining $2 \%$. A constant score of 101.749 was obtained, meaning that statistically, in the absence of $\mathrm{X}$, the magnitude of $\mathrm{Y}$ was 101.749. The coefficient score of the variable $\mathrm{X}$ is 0.480 , meaning that if the influence of $\mathrm{X}$ (teacher workload) increases by $1 \%$, there will be a decrease in $\mathrm{Y}$ (teacher performance) which is $48 \%$. The variable $X$ (teacher workload) coefficient score is negative, meaning that the teacher's workload harms Y (teacher performance). If the workload increases, the teacher's performance will decrease and vice versa. The sig score is obtained. Of $0.034<$ 0.05 , there is a significant effect of teacher workload on teacher performance in Gugus II Elementary Schools in South Kuta in the 2020/2021 academic year.

Table 10. Model Summary of Multiple Regression Analysis

\begin{tabular}{cccc}
\hline Variable & R & R Square & Adjusted R Square \\
\hline 1 & $0,425^{\text {a }}$ & 0,181 & 0,143 \\
\hline
\end{tabular}

Based on the table, it can be seen that the score of R2 is 0.143 . It means that independent variables (emotional intelligence and teacher workload) influence the dependent variable (teacher performance) are $14.3 \%$, and other variables influence $85.7 \%$.

Tabel 11. Overview of independent variables Sig.

\begin{tabular}{lccccc}
\hline Model & $\begin{array}{c}\text { Sum of } \\
\text { Squares }\end{array}$ & Df & $\begin{array}{c}\text { Mean } \\
\text { Square }\end{array}$ & F & Sig. \\
\hline Regression & 320.606 & 2 & 160.303 & 4.740 & $.014 \mathrm{~b}$ \\
Residual & 1454.263 & 43 & 33.820 & & \\
Total & 1774.870 & 45 & & & \\
\hline
\end{tabular}

Based on the table, it can be seen that the significance score obtained is $0.014<0.05$, so that it can be interpreted that there is a simultaneous influence of X1 (emotional intelligence) and X2 (teacher workload) on Y (teacher performance).

Table 12. Multiple Regression Coefficient

\begin{tabular}{clllll}
\hline Model & \multicolumn{2}{l}{$\begin{array}{l}\text { Unstandardized } \\
\text { Coefficients }\end{array}$} & $\begin{array}{l}\text { Standardized } \\
\text { Coefficients }\end{array}$ & T & Sig. \\
\cline { 2 - 4 } & $\mathrm{B}$ & Std. Error & Beta & & \\
\hline (Constant) & 84.657 & 13.238 & & 6.395 & .000 \\
X1 & .234 & .113 & .312 & 2.076 & .044 \\
X2 & -.667 & .230 & -.436 & -2.906 & .006 \\
\hline
\end{tabular}


Based on Table 12, the constant score and the coefficient score for the $\mathrm{X} 1$ and $\mathrm{X} 2$ variables in column $\mathrm{B}$ in the table and the significance score of the $\mathrm{X} 1$ and $\mathrm{X} 2$ variables, the regression equation can be determined. The constant score of 84,657 means that statistically, without $\mathrm{X} 1$ and $\mathrm{X} 2$, the magnitude of $\mathrm{Y}$ is 84,657 . The variable $\mathrm{X} 1$ (Emotional Intelligence) has a positive coefficient score, meaning that $\mathrm{X} 1$ (Emotional Intelligence) has a positive effect on Y (Teacher Workload). So it can be interpreted that the higher the Emotional Intelligence, the higher the teacher's performance, and vice versa. The variable X2 (Teacher Workload) has a negative coefficient score, meaning that X2 (Teacher Workload) harms Y (Teacher Workload) so that it can be interpreted that the higher the teacher's workload, the lower the teacher's performance, and vice versa.

Based on hypothesis testing I, it was found that emotional intelligence did not significantly affect teacher performance at Gusus II Elementary School in South Kuta. In this study, the emotional intelligence variable has a positive coefficient score so that if emotional intelligence is increased, the teacher's performance will also increase, and vice versa. This study also contradicts the results of previous studies that state that emotional intelligence influences performance (Priadi, 2018; Purwanti, 2018; Yani, 2016). Similar research results show that emotional intelligence has no significant effect on performance (Akimas, 2016; Haryati, 2018; Joseph, 2018). Emotional intelligence is influenced by several factors, including psychological, physical, and environmental factors (Asy'ari, Ekayati, \& Matulessy, 2014; Satriyono \& Vitasmoro, 2018). Teacher performance is influenced by several factors, both internal and external. Someone with good emotional intelligence can control his emotions well, so that good emotional management does not affect the resulting performance (Erdiyanti, 2018; Satriyono \& Vitasmoro, 2018). Following previous research that states that an employee or worker who can control his emotions well will produce good performance (Fitriastuti, 2013).

Based on the second hypothesis testing, it was found that the teacher's workload has a significant influence on teacher performance in Gugus II Elementary Schools throughout South Kuta for the 2020/2021 Academic Year. Based on the study results, the teacher's workload has a negative coefficient score, so it means that if the teacher's workload increases, the teacher's performance will decrease and vice versa. The results of this study are in line with the results of previous studies stated that there is a significant effect of workload on teacher performance (P. Y. Astuti, 2017; Jalil, 2019; Purwanti, 2018). workload is a responsibility and task that must be carried out by someone and done within a certain time (Irawati, 2017; Jalil, 2019). If the workload or task is given more than the person's capacity and ability, it will decrease its performance. Previous research has also stated that one of the negative impacts of workload is decreased work quality due to fatigue both physically and psychologically (Irawati, 2017).Testing the third hypothesis was found that there was a joint influence of emotional intelligence and teacher workload on teacher performance in Gugus II Elementary Schools throughout South Kuta for the 2020/2021 Academic Year. The results of this study are in line with the results of previous studies, which state that there is a significant influence of emotional intelligence and workload on performance (Trisnawati, 2018; Zulaikha, 2019). It can be concluded that internal and external factors simultaneously affect the performance of elementary school teachers. External factors, the workload has a greater influence on teacher performance. The implications of this research have a positive impact on emotional intelligence and workload on teacher performance.

\section{Conclusion}

Based on the research conducted, it can be concluded that emotional intelligence and teacher workload affect teacher performance in Gugus II Elementary Schools in South Kuta for the 2020/2021 Academic Year. 


\section{References}

Akimas, H. N. (2016). Pengaruh Kecerdasan Intelektual (IQ), Kecerdasan Emosional (EQ), Kecerdasan Spiritual (SQ) Terhadap Kinerja Pegawai Inspektorat Provinsi Kalimantan Selatan. Jurnal Wawasan Manajemen, 4(3), 259-271. https://doi.org/http://dx.doi.org/10.20527/jwm.v4i3.99.

Ananda, R., \& Fadhli, M. (2018). Statistik Pendidikan, Teori dan Praktik dalam Pendidikan. Medan: CV.Widya Puspita.

Astuti, H., Rokhmat, J., \& Sudirman. (2017). Pengaruh Lingkungan Kerja dan Motivasi Berprestasi Terhadap Kinerja Guru Madrasah Ibtidaiyah di Kecamatan Alkmel Kabupaten Lombok Timur. Jurnal Ilmiah Profesi Pendidikan, (1). https://doi.org/https://doi.org/10.29303/jipp.v2i1.42.

Astuti, P. Y. (2017). Pengaruh Kepemimpinan, Iklim Kerja Dan Beban Kerja Terhadap Kinerja Guru Pada Smp Negeri 3 Dumai. Jurnal Online Mahasiswa, 4(1), 313-322. Retrieved from https://jom.unri.ac.id/index.php/JOMFEKON/article/view/13451.

Asy'ari, M., Ekayati, I. N., \& Matulessy, A. (2014). Konsep diri, Kecerdasan Emosi dan Motivasi Belajar Siswa. Persona: Jurnal Psikologi Indonesia, 3(1). https://doi.org/https://doi.org/10.30996/persona.v3i01.372.

Darma, W. (2018). Pengaruh Beban Kerja dan Burnout (Kejenuhan Kerja) Terhadap Intensi Turnover Guru Sekolah Menengah Pertama Di Sekolah Bercirikan Agama Buddha Di DKI Jakarta. Jurnal Manajemen Pendidikan, 9(2), 131-140. Retrieved from http://journal.unj.ac.id/unj/index.php/jmp/article/view/10801.

Darmadi, H. (2015). Tugas, Peran,Kompetensi, dan Tanggung Jawab Menjadi Guru Profesional. Jurnal Edukasi, https://doi.org/http://dx.doi.org/10.31571/edukasi.v13i2.113

Dewi, R. S. (2018). Kemampuan Profesional Guru Dan Motivasi Kerja Terhadap Kinerja Mengajar Guru Sekolah Dasar. Jurnal Administrasi Pendidikan, 25(1), 150-158. https://doi.org/https://doi.org/10.17509/jap.v25i1.11581.

Dharmawan, N. A. S. (2013). Pengaruh Kecerdasan Intelektual, Kecerdasan Emosional, Dan Kecerdasan Spiritual Pada Profesionalisme Kerja Auditor. Jurnal Ilmiah Akutansi Dan Humanika, 3(2). https://doi.org/http://dx.doi.org/10.23887/jinah.v2i2.1677.

Erdiyanti. (2018). Pengaruh Kecerdasan Emosional dan Komitmen Organisasi Terhadap Kinerja Guru di SMA Negeri 1 Kendari. Shautut Tarbiyah, 24(2), 204-220. https://doi.org/https://doi.org/10.31332/str.v24i2.1165.

Fitriastuti, T. (2013). Pengaruh Kecerdasan Emosional, Komitmen Organisasional Dan Organizational Citizenship Behavior Terhadap Kinerja Karyawan. Jurnal Dinamika Manajemen, 4(2), 103-114. Retrieved from https://journal.unnes.ac.id/nju/index.php/jdm/article/view/2753.

Haryati. (2018). Pengaruh Kecerdasan Emosional, Kecerdasan Spritual Dan Motivasi Terhadap Kinerja Guru Madrasah Aliyah Negeri 1 Malang. Jurnal Ilmiah Riset Manajemen, 7(2), 12-23. Retrieved from https://ejournal.unmas.ac.id/index.php/emas/article/view/1667.

Hasibuan, S. ., \& Munasib, A. (2020). Pengaruh Kepemimpinan Motivasi dan Disiplin Kerja Terhadap Kinerja Karyawan. Maneggio : Jurnal Ilmiah Magister Manajemen, 3(2), 247-258. https://doi.org/Pengaruh Kepemimpinan Motivasi dan Disiplin Kerja Terhadap Kinerja Karyawan..

Irawati, R. (2017). Analisis Pengaruh Beban Kerja Terhadap Kinerja Karyawan Operator Pada PT. Giken Precision Indonesia. Jurnal Inovasi Dan Bisnis, 5(1), 53-58. https://doi.org/https://doi.org/10.35314/inovbiz.v5i1.171.

Jalil, A. (2019). Pengaruh Beban Kerja, Stres Kerja dan Lingkungan Kerja Terhadap Kinerja 
Guru Madrasah Aliyah Negeri 2 Kota Palu. Jurnal Ilmu Perbankan Dan Keuangan Islam, 1(2), 117-134. https://doi.org/https://doi.org/10.24239/jipsya.v1i2.14.117-134

Joseph, J. (2018). Pengaruh Kecerdasan Emosional Terhadap Kinerja Guru Sekolah Menengah Pertama Swasta di Bandung. Bandung.

Karlina, E., Sari, A. I. candra, \& Munzir. (2014). Pengaruh Kecerdasan Emosional Dan Persepsi Iklim Organisasi Terhadap Kinerja Guru. Jurnal Ilmiah Kependidikan, 1(2), 93-100. https://doi.org/http://dx.doi.org/10.30998/fjik.v1i2.343.

Krissandi, \& Rusmawan. (2015). Kendala Guru Sekolah Dasar Dalam Implementasi Kurikulum 2013. Jurnal Pendidikan Indonesia, 34(3), 457-467. https://doi.org/https://doi.org/10.21831/cp.v3i3.7409.

Kristiantari, M. R. (2015). Analisis kesiapan guru sekolah dasar dalam mengimplementasikan pembelajaran tematik integratif menyongsong kurikulum 2013. JPI (Jurnal Pendidikan Indonesia), 3(2). https://doi.org/http://dx.doi.org/10.23887/jpiundiksha.v3i2.4462.

Lonto, A. L. (2016). Pengaruh Kecerdasan Emosional Dan Lingkungan Keluarga Terhadap Kinerja Guru Pendidikan Kewarganegaraan SMA di Sulawesi Utara. Jurnal Inovasi Dan Teknologi Pembelajaran, 1(4), 313-322. https://doi.org/http://dx.doi.org/10.17977/um031v2i22016p313.

Mangkunegara, A. . A. P. (2015). Kecerdasan Emosi,Stres Kerja, dan Kinerja Guru SMA. Jurnal Kependidikan, 45(2), 142-155. https://doi.org/https://doi.org/10.21831/jk.v45i2.7491.

Priadi, A. (2018). Pengaruh Kecerdasan Intelektual, Kecerdasan Emosional Dan Kecerdasan Spiritual Terhadap Kinerja Guru(Studi Kasus SMA Negeri 6 DAN SMA Negeri 8 Kota Tangerang Selatan). Jurnal Semarak, 1(3), 62-77. https://doi.org/http://dx.doi.org/10.32493/smk.v1i3.2260.

Purwanti, E. (2018). Pengaruh Budaya Organisasi, Lingkungan Kerja, Beban Kerja Dan Disiplin Terhadap Kinerja Guru SMA Muhammadiyah 1 Gresik. Jurnal Manajerial, 5(1), 64-74. https://doi.org/http://dx.doi.org/10.30587/manajerial.v5i1.740.

Sabon, S. S. (2020). Problematik Pemenuhan Beban Kerja Guru Dan Alternatif Pemenuhannya (Studi Kasus Di Kota Depok Provinsi Jawa Barat). Jurnal Penelitian Kebijak An Pendidikan, 13(1), 27-44. https://doi.org/DOI : 10.24832/jpkp.v13i1.345.

Salbiyah, S., \& Mahardhika, B. W. (2017). Pengaruh Motivasi Kerja Terhadap Kinerja Tenaga Kependidikan Universitas Muhammadiyah Surabaya Tahun 2016. Balance, 14(2). https://doi.org/http://dx.doi.org/10.30651/blc.v14i02.1280.

Satriyono, G., \& Vitasmoro, Pa. (2018). Pengaruh Kecerdasan Emosional Terhadap Kinerja Guru Di SMP Negeri 4 Kediri. Jurnal Ekonomi Universitas Kediri, 3(1), 31-45. https://doi.org/https://doi.org/10.30737/ekonika.v3i1.104.

Sunarso, \& Kusdi. (2010). Pengaruh Kepemimpinan, Kedisiplinan, Beban Kerja Dan Motivasi Kerja Terhadap Kinerja Guru Sekolah Dasar. Jurnal Manajemen Sumber Daya Manusia, 4(1), 72-79.

Supriyadi, N. Y., \& Sarino, A. (2019). Kunci untuk meningkatkan kinerja. Jurnal Pendidikan Manajemen Perkantoran, 4(1), 55-66. https://doi.org/https://doi.org/10.17509/jpm.v4i1.14955.

Trianingsih, R. (2016). Pengantar Praktik Mendidik Anak Usia Sekolah Dasar. Al Ibtida: Jurnal Pendidikan Guru MI, 3(2), 197. https://doi.org/10.24235/al.ibtida.snj.v3i2.880.

Trisnawati, W. (2018). Pengaruh Beban Kerja, Stres Pekerjaan, Dan Kecerdasan Emosional Terhadap Kinerja Karyawan: Studi Pada Perusahaan Umum Jaminan Kredit Indonesia Cabang Surabaya.

Utami, \& Hasanah. (2019). Kompetensi Profesional Guru Dalam Penerapan Pembelajaran Tematik Di SD Negeri Maguwoharjo 1 Yogyakarta. Pionir Jurnal Pendidikan, 8(2). 
https://doi.org/http://dx.doi.org/10.22373/pjp.v8i2.6232.

Wahyono, P., Husamah, H., \& Budi, A. S. (2020). Guru profesional di masa pandemi COVID-19: Review implementasi, tantangan, dan solusi pembelajaran daring. Jurnal Pendidikan Profesi Guru, 1(1), 51-65. https://doi.org/https://doi.org/10.22219/jppg.v1i1.12462.

Wardani, I. G. A. K. (2012). Mengembangkan Profesionalisme Pendidik Guru (Kajian Konseptual Dan Operasional). Jurnal Pendidikan, 13(1). https://doi.org/https://doi.org/10.33830/jp.v13i1.357.2012.

Wuryandani, Sapriya, \& Budimansyah. (2014). Pendidikan Karakter Disiplin Di Sekolah Dasar. Cakrawala Pendidikan, 33(2), 286-295. Retrieved from https://journal.uny.ac.id/index.php/cp/article/view/2168/pdf.

Yani, A. S. (2016). Pengaruh Kecerdasan Intelektual Dan Kecerdasan Emosional Terhadap Kinerja Karyawan Dengan Profesionalisme Sebagai Variabel Intervening (Studi Empiris Terhadap PT. JNE service Center Utara 1). Media Studi Ekonomi, 19(2), 114. Retrieved from http://journal.uta45jakarta.ac.id/index.php/MSE/article/view/558.

Yanti, D. D., \& Saluy, A. B. (2019). Pengaruh Kepemimpinan Motivasi Dan Beban Kerja Terhadap Kinerja Guru Di Sma Negeri 7 Bengkulu Selatan. Jurnal Ilmiah Manajemen \& Bisnis, 3(1), 52-59. https://doi.org/https://dx.doi.org/10.22441/indikator.v3i1.5167.

Yulianingsih, \& Sobandi. (2017). Kinerja Mengajar Guru Sebagai Faktor Determinan Prestasi Belajar Siswa. Mamper Jurnal Manajemen Perkantoran, 2(2). https://doi.org/https://doi.org/10.17509/jpm.v2i2.8105.

Zahriati. (2016). Kecerdasan Emosi Mahasiswa Prodi Manajemen Pendidikan Islam Fakultas Tarbiyah Dan Keguruan Uin Ar-Raniry. Jurnal Intlektualita, 4(1), 1-23. Retrieved from https://jurnal.ar-raniry.ac.id/index.php/intel/article/view/3941.

Zulaikha, I. (2019). Analisis Pengaruh Beban Kerja dan Kecerdasan Emosional Terhadap Kinerja Pelaksana PNS dengan Kepuasan Kerja Sebagai Variabel Intervening (Studi Pada Kesekretariatan Panwascam di Kabupaten Kebumen). Jurnal Ilmiah Mahasiswa Manajemen,Bisnis,Dan Akutansi, 1(1). https://doi.org/https://doi.org/10.32639/jimmba.v1i1.400. 